\title{
Gaps in Executive and Worker Compensation as an Organizational and Management Challenge
}

\author{
Donovan A. McFarlane \\ Assistant Professor of Business, College of Business \\ Westcliff University \\ 4199 Campus Drive, Irvine, California 92612 \\ Email: donovanmcfarlane@westcliff.edu
}

Adjunct Professor of Marketing, Huizenga School of Business and Entrepreneurship

Nova Southeastern University

3301 College Avenue, Fort Lauderdale, Florida 33314

Email: donovan@nova.edu

Doi:10.5296/jebi.v2i1.6970 URL: http://dx.doi.org/10.5296/jebi.v2i1.6970

\begin{abstract}
This paper examines the gaps in chief executive officer (CEO) and worker compensation by exploring the vital data of 10 corporations as uncovered in a study by NerdWallet.com on the differences in hourly compensation between CEOs and average hourly workers or employees. The author examines the problem of excessive compensation for CEOs as a major organizational challenge that affects perceptions of fairness by stakeholders, especially employees or workers whose contributions to organizational performance and success are not being adequately rewarded, but instead transferred to CEOs and other executives as companies increase revenues and profits through the sweat and toil of ordinary workers. The author argues that executive compensation should be linked to organizational results and performance, and examines the standards and considerations for determining fair wage and compensation, and from examining vital data on CEO compensation and average worker compensation, explores the implications for organizational change, including consideration of quality work life (QWL) investments. Several recommendations are made for meeting the challenge of excessive CEO compensation to include the following: (1) developing new approaches or methods of compensation that take worker rewards into consideration; (2) limiting CEO or executive compensation relative to established multiple of the average
\end{abstract}


worker's wage; (3) intervention and petition from governmental and administrative agencies including workers' rights organizations for change; and (4) more compassionate leadership and management by organizational CEO and executives with increased concern for workers' well-being.

Keywords: Employee Retention, Employee Satisfaction, Excessive Compensation, Executive Compensation, Fair Wage, Organizational Citizenship Behavior (OCB), Quality Work Life (QWL), Stakeholders.

\section{Introduction}

When it comes to the compensation debate there are two dominating themes or issues: gender compensation gap and executive compensation (Grey-Bowen \& McFarlane, 2010). Executive compensation or pay has been a major problem and challenge in improving workers' salaries, job satisfaction, and perceived fairness as the CEOs of large corporations are compensated at the cost of paying workers better salaries and improving their working conditions, and subsequently, their standard of living through opportunities for both professional and social mobility. The more compensation that companies provide for their CEOs or chief executive officers as well as other executives, the less will be available for investment in workers as rewards for their contributions to the company's performance and growth and the achievement of strategic goals.

There is some level of relationship between compensation levels and employee motivation and satisfaction that has been established in management studies and literature. While there are some disagreements in the literature, there is a general consensus that happy or satisfied workers are more productive overtime. According to Nelson and Quick (2007) the links between satisfaction and performance has been widely explored with one view holding that satisfaction causes good performance and another holding that good performance causes satisfaction. Nelson and Campbell (2007) argue that research has provided modest support for both views; there is no simple direct relationship identified between performance and satisfaction, and this may stem from the difficulty of establishing attitudinal-behavioral link.

This is also asserted by Staw (1986) who states that "psychologists have acknowledged the fact that performance and satisfaction are not tightly linked" (p. 41). However, what Nelson and Quick (2007) have asserted is that job satisfaction is related to organizational citizenship behavior (OCB) or behavior that is above and beyond the call of duty. Given this recognition, satisfied employees are more likely to help their coworkers, make positive commitments about the company, and refrain from complaining when things at work are not pleasing or do not go well. Wright and Cropanzano (2000) believe that happy workers demonstrate higher levels of job-related performance behaviors than unhappy or dissatisfied workers, and thus, this should have some impact on performance.

This long recognized association should lead to the conclusion that better compensated workers will be more motivated and more productive as they feel that they are rewarded fairly for work done. With this in mind the concern with CEO compensation stems from the existing low levels of compensation that the average worker receives, especially considering 
cost of living and comparison to what CEOs earn, especially where some are mere figureheads for their companies.

The world of executive compensation is a fascinating one by virtue of the constant surprise the public and watchdog organizations receive when the salaries of America's and the world's top CEOs are occasionally the focus of news and debates. Often, the public as well as average workers are unaware of just how much compensation CEOs and other executives in large corporations receive until studies like that by NerdWallet.com are released. Only then does the average worker realizes how poorly compensated he or she is, and that what should be rewards for additional contributions made by the average workers' efforts really end up in the pockets of already extremely affluent CEOs. This can be both disheartening, and at the same time, it defeats the idealized dreams of workers who come to accept Marxian theory that our society and economy are truly built on the haves and have-nots where the worker class (proletariats) are constantly oppressed and robbed by the economic and financial ruling class (bourgeois), and that the system offers no remedy in reversing this course or bringing justice in the form of fair wage or fair compensation. Thus, many average workers seem rather distant and unconcerned when it comes to how much their CEOs receive since they see no possibility or low possibility of their conditions being improved in terms of increased salaries and benefits despite their organizations earning more revenues and generating more profits as a direct result of their labor. To some degree this is understandable since it has been a traditional approach of our society and social institutions to reward leaders for what they really could not achieve single-handedly despite being the ones to develop original ideas, strategies, or approach for such. Executives and organizations must strive to reward average workers more equitably for their contributions to company success.

\section{Literature Review}

According to Beatty and Zajac (1994), there is much ambiguity and conflict surrounding executive compensation. High levels of executive compensation have triggered intense debate over excess of rewards and congruence with performance and productivity of firms (Gordon, 2004). It was in the early 1990s that CEO compensation achieved national attention and according to Murphy (1994), few issues in the history of modern corporation has generated the fury aroused by the escalation of chief executive officer (CEO) compensation in the United States. This debate is generally framed in relation to the cost of this excess compensation to the average worker. Most of the concern seems to about the compensation of professional CEOs rather than founder CEOs, for as He (2008) notes, founder CEOs tend to earn smaller incentive compensation and smaller total compensation than professional CEOs.

In determining executive compensation, firms' boards create managerial incentives consistent with those of firms' owners, both by setting compensation and following management change policies which benefit shareholders (Coughlan \& Schmidt, 1985). As Boyd (2006) notes, board of directors has been identified as a key internal control mechanism for setting CEO compensation. This means that executive compensation is mainly an internally-determined decision as boards of directors do influence both the level and composition of executive compensation (Sapp, 2008). CEO compensation is seen as having complex links to several 
factors such as firm size, complexity, performance, CEO power, board vigilance, and the CEO's human capital (Finkelstein \& Hambrick, 1989). Another factor cited by Sridharan (2005) in the determination of and level of executive compensation is CEO influence; "CEO influence over the board is an additional explanation for the size of CEO pay" (p. 51). In support of this, Grabke-Rundell and Gomez-Mejia (2002), and Goldberg and Idson (1995) argue that agency theory alludes to a power imbalance favorable to the executives, allowing them to pursue their self-interests in the form of large pay packages. Worker compensation still does not seem to be a consideration in arriving at what executives are compensated. However, there seems to be a need to consider this from the perspectives of excess and equity, especially given the negative focus on executive compensation (Core, Guay, \& Larcker, 2008). As a result of this negative focus, corporate control practices now require a more unified perspective on top management compensation (Beatty \& Zajac, 1994).

While Mehran (1995) argues that firms performance is positively related to the percentage of equity held by managers and to the percentage of their compensation that is equity-based, there needs to be more research comparing executive compensation with those of average workers in order to ascertain potential impact on workers' motivation and morale, perception of equity, and the consequential effect on performance and productivity. While the data shows that substantial variability in the level of compensation among firms of comparable size exists (Kostiuk, 1990), this variability seems to decrease when it comes to the compensation of the average workers of these firms.

According to Carr (1997), when it comes to CEO compensation, compensation is often declared excessively high, unrelated to the firm's performance, or, if related, only to short-term performance. Limitations on executive compensation is still a matter of firm decision as determined by board of directors, firm's earnings and profits, as well as performance and growth. While there has been some impact on determination of executive compensation by factors such as the Sarbanes-Oxley Act [SOX] (Narayanan \& Seyhun, 2005), there seems to be little in the way of law and accounting controls to limit executive compensation. Tension between the pressures for accountability and long-term decision making are also functioning to affect CEO compensation (Grossman \& Hoskisson, 1998). Kuhnen and Zwiebel (2007) have proposed a "“"managerial optimal " framework for top executive compensation, where top management sets their own compensation subject to limited entrenchment, instead of the conventional setting where such compensation is set by a board that maximizes firm value" (p. 1). However, it is best if CEO compensation is handled by others such as board of directors and shareholders in order to limit self-interest in compensation structure and levels. Shareholders do and can play a significant role in determining and influencing executive compensation. David, Kochhar, and Levitas (1998) suggests that institutional owners that have only an investment relationship with a firm can influence compensation in accordance with shareholder preferences to (1) lower CEO or executive compensation level, and/or to (2) increase the proportion of long-term incentives in total compensation.

According to Harris (2008), the major problem with executive compensation lies in the perception that current compensation practices are problematic both from the standpoint of 
distributive justice and fairness. This is especially the case when a comparison is made of CEO compensation versus the compensation of average workers across several corporations and industries. While Nichols and Subramaniam (2001) argue that, "Arguments based on comparisons between CEO pay and the pay of other individuals or jobs or between CEO pay and firm performance are shown to be an insufficient mechanism to determine the appropriateness of CEO compensation" (p. 339), the analysis of 10 major corporations' CEO compensation in this paper seem to provide a rationale basis for making such a consideration an effective measure of excessiveness.

\section{Research Methodology}

This paper uses simply descriptive method to examine executive compensation in corporate America, limiting data exploration and analysis to 10 major corporations including McDonald's Starbucks, Dollar General, Gap, TJ Max, Target, Wal-Mart, CVS Caremark, Best Buy, and AT\&T Wireless. Using secondary sources on executive compensation, the author compares the salaries of different firms' chief executive officers to their employees. The data is drawn from other studies and compilations on executive compensation and the author uses simple calculations to compare executives' salaries to those of the average workers in their firms. The author looks at total compensation for firms' CEOs, CEO hourly compensation, average worker hourly wage, CEO pay multiple (i.e. how many times the average worker's salary or wage a CEO receives), and the number of months of worker overtime that equals CEO pay. The author uses simple descriptive statistics to develop and analyze CEO annual compensation, and annual worker compensation and to ascertain the gap or difference in annual compensations between CEOs and average workers. Several sources on executive compensation are used to provide a framework for the ideas and arguments which the author presents.

\section{Discussion of findings}

\subsection{Gaps in Chief Executive Officers' and Average Workers' Compensation}

The gap in executive and employee (worker) compensation is not only alarming, but increasing despite the current attention being given to this organizational and management challenge. Table 1 below shows the gaps in CEOs' (chief executive officers) and average workers' per hour compensation for 10 major companies with the highest paid CEOs. The data in the table stems from a study by NerdWallet (Peterson, 2013). According to Lime (2013) and Peterson (2013), in a study of 100 companies for the report, the 10 companies with the highest annual CEO pay were selected to compare the disparities between executive (CEO) and worker hourly compensation. These 10 corporations or companies included McDonald's, Starbucks, Dollar General, Gap, TJ Maxx, Target, Wal-Mart, CVS Caremark, Best Buy, and AT\&T Wireless. Among the 10 companies with the highest annual CEO pay, McDonald's and Starbucks exhibited the widest gap between CEO (chief executive officer) compensation and worker compensation on an hourly basis, with Starbucks' CEO receiving an approximate $\$ 9,637$ per hour compared to the average hourly wage of $\$ 8.79$ for Starbucks' employees (Peterson, 2013; Lime, 2013). The gap between CEO (executive) compensation 


\section{I Macrothink}

Journal of Entrepreneurship and Business Innovation

ISSN 2332-8851

2015, Vol. 2, No. 1

and worker wages at McDonald's was equally alarming, with the data revealing that McDonald's CEO receives an hourly compensation of $\$ 9,247$ compared to its average hourly wage for workers at $\$ 7.73$ (Peterson, 2013; Lime, 2013). Other companies with extremely wide gaps between CEO and worker hourly compensation included Dollar General with $\$ 7,720$ for CEO compensation versus $\$ 7.67$ for workers' compensation; Gap with $\$ 8,209$ for CEO compensation versus $\$ 8.67$ for worker compensation; and as evident from Table 1, the other companies: Wal-Mart, TJ Maxx, Target, CVS Caremark, Best Buy and AT\&T Wireless also had wide gaps between executive (CEO) per hour compensation and average worker hourly wages (Peterson, 2013; Lime, 2013).

Table 1. Gaps in Executive and Worker Compensation for 10 Corporations

\begin{tabular}{|c|c|c|c|c|}
\hline & $\begin{array}{l}\text { CEO Hourly } \\
\text { Compensation }{ }^{1}\end{array}$ & $\begin{array}{l}\text { Average Worker } \\
\text { Hourly Wage }^{2}\end{array}$ & $\begin{array}{l}\text { CEO Pay } \\
\text { Multiple }\end{array}$ & $\begin{array}{c}\text { Months of } \\
\text { Worker Overtime } \\
\text { To Equal CEO } \mathrm{Pay}^{3}\end{array}$ \\
\hline 1 McDonald's & $\$ 9,247 \quad 4$ & $\$ 7.73$ & 1,196 & 3.86 \\
\hline 2 Starbucks & $\$ 9,637$ & $\$ 8.79$ & 1,096 & 3.49 \\
\hline 3 Dollar General & $\$ 7,720$ & $\$ 7.67$ & 1,007 & 3.15 \\
\hline 4 Gap & $\$ 8,209$ & $\$ 8.67$ & 947 & 2.92 \\
\hline 5 TJ Maxx & $\$ 7,256$ & $\$ 7.85$ & 924 & 2.83 \\
\hline 6 Target & $\$ 6,882$ & $\$ 8.35$ & 824 & 2.46 \\
\hline 7 Walmart & $\$ 6,898$ & $\$ 8.86$ & 779 & 2.28 \\
\hline 8 CVS Caremark & $\$ 6,777$ & $\$ 8.81$ & 769 & 2.25 \\
\hline 9 Best Buy & $\$ 6,517$ & $\$ 9.78$ & 666 & 1.86 \\
\hline 10 AT\&T Wireless & $\$ 7,412$ & $\$ 13.28^{5}$ & 558 & 1.45 \\
\hline Median & $\$ 7,334$ & $\$ 8.73$ & 874 & 2.65 \\
\hline \multicolumn{5}{|c|}{$\begin{array}{l}{ }^{1} \text { Calculated by dividing CEO's total compensation from the company's annual proxy statement } \\
\text { by } 60 \text { hours a week times } 50 \text { weeks per year. }\end{array}$} \\
\hline \multicolumn{5}{|c|}{${ }^{2}$ Equals the average non-executive employee wage as obtained from www.glassdoor.com. } \\
\hline \multicolumn{5}{|c|}{$\begin{array}{l}{ }^{3} \text { Calculated based on hourly overtime rate equal to } 1.5 \text { times the average hourly wage, an } \\
\text { eight-hour workday and } 22 \text { working days per month. }\end{array}$} \\
\hline${ }^{4}$ Compensation is fo & former CEO who retire & June 30,2012 as detai & most rece & \\
\hline
\end{tabular}

Source: Lime, 2013, on NerdWallet.com (p. 1).

When we examine the data provided in Table 1, the average CEO hourly compensation among the 10 companies under examination is 874 times that of the average hourly wage for workers among these 10 companies. The largest gaps in hourly compensation between CEOs and average workers are exhibited by McDonald's at 1,196 times that of the average worker, Starbucks at 1,096 times that of the average worker, and Dollar General at 1,007 times that of the average worker (Peterson, 2013; Lime, 2013). Furthermore, both Gap and TJ Maxx compensate their CEOs at over 900 times the average worker's hourly wage, while all the other five corporations: Target, Wal-Mart, CVS, Best Buy and AT\&T Wireless compensated 


\section{MInstitute Macrothink $_{\text {Int }}$}

Journal of Entrepreneurship and Business Innovation ISSN 2332-8851

their CEOs or chief executive officers at over 500 times the hourly wage of the average worker, with Target having the widest gap between CEO and worker hourly compensation among them at 824 times the average worker, or what NerdWallet.com (2013) describes as "CEO Pay Multiple."

Further analysis and calculations using the data provided in Table 1 would indicate the disparities between CEO hourly compensation and average worker hourly wage if a 40 hour work week is assumed to range between $\$ 16,000$ annually for the lowest paid workers at $\$ 7.73$ hourly among the 10 companies - McDonald's, and \$20,000, 000 (\$20 million) for the highest paid CEO at $\$ 9,637$ hourly among the 10 companies - Starbucks. Thus, the widest gap between CEO compensation and average worker compensation overall is over $\$ 19,000,000$ (\$19 million). Table 2 below shows the estimated annual compensation for average workers and CEOs of the 10 companies presented in Table 1 above based on an assumed work week of 40 hours and 52 weeks annually without considerations for holidays and downtime because of the variability and unpredictable elements involved.

Table 2. Gaps between CEO and Worker Annual Compensation for 10 Major Companies

\begin{tabular}{|l|l|l|l|}
\hline Company & $\begin{array}{l}\text { CEO Annual } \\
\text { Compensation }\end{array}$ & $\begin{array}{l}\text { Average Worker } \\
\text { Annual } \\
\text { Compensation }\end{array}$ & $\begin{array}{l}\text { Gap or Difference } \\
\text { in Annual } \\
\text { Compensation }\end{array}$ \\
\hline 1. McDonald's & $\$ 19,233,760$ & $\$ 16,078$ & $\$ 19,217,682$ \\
\hline 2. Starbucks & $\$ 20,044,960$ & $\$ 18,283$ & $\$ 20,026,677$ \\
\hline 3. Dollar General & $\$ 16,057,600$ & $\$ 15,954$ & $\$ 16,041,646$ \\
\hline 4. Gap & $\$ 17,074,720$ & $\$ 18,034$ & $\$ 17,056,686$ \\
\hline 5. TJ Maxx & $\$ 15,092,480$ & $\$ 16,328$ & $\$ 15,076,152$ \\
\hline 6. Target & $\$ 14,314,560$ & $\$ 17,368$ & $\$ 14,297,192$ \\
\hline 7. Wal-Mart & $\$ 14,347,840$ & $\$ 18,429$ & $\$ 14,329,411$ \\
\hline 8. CVS Caremark & $\$ 14,096,160$ & $\$ 18,325$ & $\$ 14,077,835$ \\
\hline 9. Best Buy & $\$ 13,555,360$ & $\$ 20,342$ & $\$ 13,535,018$ \\
\hline 10. AT\&T Wireless & $\$ 15,416,960$ & $\$ 27,622$ & $\$ 15,389,338$ \\
\hline Mean & $\$ 15,923,440$ & $\$ 18,676$ & $\$ 15,904,764$ \\
\hline
\end{tabular}

From Table 2 above, both McDonald's and Starbucks have the highest annual CEO compensation and the widest gap between CEO and average worker annual salary. Based on the assumed 40-hour work week used to arrive at the calculations in Table 2, we can arrive at an average per week salary of over $\$ 300$ and with only one company compensating its average workers above $\$ 500$ weekly; that is AT\&T Wireless, which also has the highest annual compensation of approximately $\$ 27,000$ for the average worker compared to the lowest annual compensation paid by Dollar General to its average worker in the amount of approximately $\$ 15,954$. Overall, based on the assumed 40-hour work week and 52 weeks annually, disregarding holidays, the annual compensation for average workers among the 10 companies ranges between $\$ 15,000$ and $\$ 27,000$. The mean or average annual CEO compensation is around $\$ 16,000,000$ (\$16 million), and CEO annual compensation ranges between $\$ 15,000,000$ (\$15 million) and \$20,000, 000 (\$20 million), while the mean or average worker 
annual compensation based on the assumptions made and original data provided in Table 1 is about $\$ 18,700$ as observed in the "Mean" column in Table 2 above. The average or mean gap between CEO compensation and average worker compensation is approximately $\$ 16,000,000$ (\$16 million). Furthermore, the average weekly compensation for the CEOs of the 10 companies in the tables above based on built-in assumptions of 40-hour work week and 52 weeks per year is approximately $\$ 300,000$. Based on the hourly compensation data provided in Table 1, we can conclude that AT\&T Wireless potentially pays almost twice the salaries of McDonald's, Dollar General, and TJ Maxx with the CEOs of all three companies receiving more annual compensation than the CEO of AT\&T Wireless when we consider the absolute dollar amounts represented in these tables. The concept of "absolute dollar amount" is used because CEO compensation often includes non-monetary perks to which dollar value can be attached.

While in the original Table and data provided (Table 1), CEO pay was calculated by dividing each chief executive's total compensation as reported in the company's annual proxy statement by 60 hours a week times 50 weeks per year (Peterson, 2013), the values in Table 2 are derived from an assumption of 40 hours per week times 52 weeks per year to mirror the more traditional work hours on both sides. There is no doubt that some companies compensate their CEOs excessively compared to others. Among the 10 companies in Table 2, in solely looking at hourly compensation for CEOs, McDonald's, Starbucks and Dollar General top the list, followed by Gap, TJ Maxx, Target, Wal-Mart, CVS Caremark, Best Buy and AT\&T Wireless (Peterson, 2013). However, when calculated based on the in-built assumptions of Table 2, Best Buy reflects the lowest annual CEO compensation among the 10 companies, and Starbucks the highest, followed by McDonalds. Overall, it is difficult to compare CEO compensation other than in absolute dollar amounts since some companies afford their CEOs greater perks than others and whose monetary value might vary significantly. Based on the calculations in Table 2, from the per hour data provided in Table 1, and the assumptions built into Table 2, the three highest paid CEOs are those of Starbucks, McDonalds, and Gap respectively, and the three lowest paid (speaking comparatively) CEOs are those of Best Buy, CVS Caremark, and Target respectively. While there are other significant information to be gleaned from the above tables and data, the most striking is the obvious gaps between CEO and average worker hourly and annual compensations.

The excess in executive compensation and resulting gap between executives' and ordinary employees' salaries is not just reflective of the traditional corporation or traditional private business sector, but is a major problem in the public sector of the higher education industry as well. For example, in a May 19, 2014 article in 24/7Wall St. Newsletter, it was reported that over nine public college presidents in the United States made over \$1 million dollar in 2013, as gleaned from The Chronicle of Higher Education's "Executive Compensation at Public Colleges" fiscal year 2013 edition, which reviewed pay at 227 public universities and college systems (McIntyre, 2014). The nine public college/university presidents whom received \$1 million or more as compensation for 2013 included the following: Gordon Lee of Ohio State received \$6.057 million, Bowen Loftin of Texas A\&M/College Station received \$1.636 million, Hamid A. Shirvani, the Chancellor of North Dakota University system received \$1.311 million, 
Renu Khator, the Chancellor and President at University of Houston's main campus received $\$ 1.266$ million, Sally Mason from the University of Iowa received \$1.140 million, Michael A. McRobbie, the President of Indiana University at Bloomington received \$1.112 million, Michael Adams of the University of Georgia received \$1.075 million, V. Gordon Moulton, the President of the University of South Alabama received \$1.072 million, and Mary Sue Coleman at the University of Michigan received \$1.037 million (McIntyre, 2014). While this trend is rather disturbing, but not surprising given the current and rising costs of college education, there was one rather strange exception to excessive compensation among public college and university presidents or CEO; F. King Alexander, the President and Chancellor of the Louisiana State University at Baton Rouge reportedly made only \$14,684 in 2013.

\section{Research Results}

\subsection{Linking Executive Compensation To Results}

Given their current excessive compensation and privileges, CEO salaries should be tied to results such that an executive whose company loses money should earn less than an executive whose company makes a profit. Moreover, this would only make sense because an executive's excess salary when compared to other workers or members of the organization must be accounted for, and the best basis of accountability is his or her contribution to the company's earnings or revenues via profits. In Corporate America, executives receive so much money for their salaries that it never fails to alarm the public and ordinary organizational members. The rationale given for these high salaries is always their contribution to overall profit earnings and organizational performance and success from a financial viewpoint. Thus, when the company loses money it stands to reason and should be expected that they are compensated less, and when it earns more money in terms of increased profits stemming from their leadership, they should earn more money. This is why bonus is such a large part of executive salaries; they are compensated for their contributions to profitability earnings through their ideas, strategies, leadership, and management of organizational resources and processes to achieve shareholder's and company goals. However, the contributions to revenue alone cannot justify excessive compensation as seen in Table 1 and Table 2 above when compared to average worker annual compensation.

While many executives are extraordinary leaders and manage their companies effectively and efficiently to create new streams of revenues and increase profits, there must be a cap on CEO salaries in consideration of workers and their need for increased compensation to reward them for their contributions, and provide better working conditions including more training, more opportunities for advancement and promotion, and to increase health and other benefits as part of quality work life (QWL) balance. While CEOs and other executives might devise plans and strategies, and make important corporate and business level strategic decisions that increase revenue and profits for their companies, these ideas and strategies are generally implemented through ordinary employees or workers working harder and more diligently in meeting changed organizational and market approaches and demands to value creation and provision. For example, a CEO might successfully negotiate a merger or acquisition that brings millions of dollars and open up a new or wider market for a company, but the average workers must 
work harder and cooperate on several levels to make such plans or strategy a long-run success. Average hourly workers engage in the footwork or practices that put CEO and executive plans to the test and create the value and meet the performance levels they envision in their glass towers. Therefore, the contribution of the average worker to increased revenue and profits must be rewarded with increased monetary compensation at the least and better working conditions and opportunities for advancing professionally and socially at the most.

\subsection{Standards for Determining Fair Wage and Compensation}

Given the concern over executive compensation that affects stakeholders and worker perceptions about companies as well as their loyalty and motivation, companies should begin to ask themselves several questions including the following: What standards should be used to establish a fair wage? Are the standards for executives different from those for hourly workers? What factors should determine what someone deserves for pay?

Wage issues have remained a tough challenge for lawmakers and business organizations alike. This is especially true when we consider wage gaps existing in corporate America, especially as evident between executives and non-executives, and even between the genders and races. There are certain general standards that should be used to establish fair wage. These include: (1) management and job responsibility as to whether an individual is a manager or regular employee in the company and implications for level of skills, responsibility, and tasks; (2) level of accountability and responsibility for organizational processes and tasks; (3) experience and education as evident in years on the job and credentials necessary for competently completing the job; (4) type of technical, interpersonal, and conceptual skills required and applied in performing job functions; (5) the type of risks undertaken in completing the job and job tasks; that is, the non-hazardous versus hazardous nature of a job; (6) the sacrifices incurred in professional development such as travel and other expenses; (7) level of expertise in a particular area or job function; (8) the market and labor demand concerning a profession or field; and (9) value-added contributions to organizational productivity and success.

The standards for executives are obviously different from those for hourly workers. Thus, the fairness of executive wage or salary requires different consideration. DesJardins (2011) points to argument that executive salaries are based on company agreement with executives as argued by proponents for high executive wage, and also that executives have different skills set and duties in the organization. Furthermore, consistent with the factors listed in the paragraph above, it can be argued that they have different levels of responsibility and accountability, and higher levels of skills as they are generally seen by management theorists to have jobs that demand higher conceptual/problem solving skills than regular laborers (Jones \& George, 2009). Furthermore, executives engage in strategic planning and focus on maintaining the company from a broader perspective which secures everyone's job. The standards by which executives are judged must be different because they do a different type of job - they lead and manage, while hourly workers do more of the menial tasks.

There are several factors that determine what someone deserves for pay. These include some of those factors mentioned above, including (1) their position in the organization as to 
whether they are a manager, leader, or regular worker; (2) their level of expertise and knowledge; (3) time on the job; (4) their value-added contribution or marginal contribution to organizational revenue; (5) the value and cost of professional development; and (6) performance appraisal and evaluation results. In some cases many of these more objective standards discussed above are not applied in determining compensation for either executives or hourly workers. Sometimes practices such as nepotism, discrimination, and corruption impact compensation levels.

\subsection{Implications for Organizational Change}

Organizations should strive for fairness in compensating both executives and workers, but must be aware of the concept of "excessive compensation" as it affects perceived fairness from the perspective of workers and other stakeholders including customers or clients, the community, administrative agencies and government. This further contributes to the development of a negative organizational image and reputation where the organization is seen as driven by greed and valuing the CEO or executives over ordinary workers. Excessive compensation can be construed of as rewarding one individual too much while rewarding others too little for work done. Compensation is excessive when it is multiple times that of the average worker and on a comparative level cannot be accounted for as stemming from physical labor or labor as defined by work efforts. As seen in Table $\mathbf{1}$ above, the compensation for all CEOs form the 10 companies is at least 500 times that of their average workers. For example, the compensation for McDonald's CEO is 1196 times that of its average worker, the compensation for Starbucks CEO is 1096 times that of its average worker, the compensation for Dollar General's CEO is 1007 times that of its average worker, for Gap and TJ Maxx over 900 times that of their average worker, and all the remaining companies compensate their CEOs between 500 and 825 times the compensation of their average hourly workers.

Given the extremely wide and proliferating gap between executive and average worker compensation, organizations have a responsibility to carefully consider the implications of this in terms of the negative impact on employee satisfaction, motivation, loyalty, and perceptions from both employees and the public. Change is possible when organizations begin to think about quality work life (QWL) and its importance to sustainable business. Organizations must invest in their worker's health and education by compensating the average worker more so that that they can afford a reasonable standard of living, maintain health, and establish decent balance in life. Employees who are overworked and underpaid are employees who are being abused and taken advantage of by their organizations while their CEOs and other executives live extravagant lives. Changing organizational compensation approaches and methods might significantly improve the compensation afforded average workers. However, this will require both political and legal challenges from government and administrative bodies such as worker or employee unions, and employees themselves banding together to demand better working conditions, more opportunities, and most importantly, higher salaries. Organizations, especially corporations that see labor costs as a highly negative factor eating into revenue are especially opposed to increased labor costs, and hence increasing the compensation for average workers. This therefore requires 
fair-minded and ethical CEOs and leaders who are just and have compassion and concern for their workers to initiate any changes in compensation structure and levels. Moreover, most CEOs do not think that they are overpaid, and therefore, are unwilling to give up any amount of their compensation as part of bettering conditions and increasing salaries for their average workers.

\section{Conclusions}

There is a need for increased and continuous attention to this major organizational, management and corporate challenge. Far too many executives are receiving excessive compensation at the cost of worker satisfaction and fair treatment. Workers should be compensated fairly for their contributions to organizational performance and success. Organizations should develop a chart of limitation on compensation. For example, having a rule approved by a board of directors and the organizational shareholders and members that no one should be compensated above a certain level representing a certain multiple of average worker compensation could be a unique way of putting a cap on executive salary or compensation. A rule limiting CEO compensation only to a multiple of 10 or 20 times the average worker's compensation would limit most CEOs compensation considerably. Another worthwhile considering in remedying the concern over executive compensation as an excess is for organizations to start considering quality work life (QWL) and start investing in opportunities for improved working conditions, worker opportunities, rewards and compensation. Some organizations do an excellent job of offsetting low employee compensation by having great benefits, having a safe and enjoyable work environment with recreational and leisure facilities such as gyms, paying for scholarships for university higher education training, paid vacations, paid sick time, awarding scholarships to the children of employees, as well as supporting initiatives and programs in employees' communities, and contributing to initiatives supported by employees, among other things.

While organizational efforts aimed at increasing employee rewards are commendable and integrated as part of social responsibility actions in communities, what matters most to employees is receiving adequate and fair compensation for the work they do. This especially becomes critical when employees are aware of the excessive compensation organizational CEO and executives receive relative to their own. The cost of living has increased dramatically and the average worker already struggles to maintain self and household in today's economy. Therefore, the best reward for work is seen as increased compensation along with the opportunity to professionally advance while increasing the potential for higher compensation. This is very simple to understand and organizations must implement changes that provide for this possibility.

Administrative agencies such as government and community organizations, workers' rights unions, and political and legal lobbyists must petition large corporations to reduce CEO salaries and compensate their employees more fairly. Organizational CEOs must become more compassionate in their approaches to leading and managing their members by recognizing that workers need proper and adequate compensation to sustain and improving their living standards, as well as to remain loyal and contribute more to the organization. 
Increased compensation for the average worker will lead to increased employee retention, decreased turnover, and higher work performance, and increase quality services and products for customers. Organizations and society have a vested interest in increasing worker compensation.

\section{References}

Beatty, R. P., \& Zajac, E. J. (1994). Managerial incentives, monitoring, and risk bearing: A study of executive compensation, ownership, and board structure in initial public offerings. Administrative Science Quarterly, Vol. 39, No. 2 (Jun., 1994), 313-335.

Boyd, B. K. (1994). Board control and CEO compensation. Strategic Management Journal, 15(5), 335-344.

Carr, L. L. (1997). Strategic determinants of executive compensation in small publicly traded firms. Journal of Small Business Management, 35(2), 1-12.

Core, J. E., Guay, W., \& Larcker, D. F. (2008). The power of the pen and executive compensation. Journal of Financial Economics, 88(1), 1-25.

Coughlan, A. T., \& Schmidt, R. M. (1985). Executive compensation, management turnover, and firm performance: An empirical investigation. Journal of Accounting and Economics, 7(1), 43-66.

David, P., Kochhar, R., \& Levitas, E. (1998). The effect of institutional investors on the level and mix of CEO compensation. Academy of Management Journal, 41(2), 200-208.

DesJardins, J. (2011). An Introduction to Business Ethics ( $4^{\text {th }}$ Ed.). New York: McGraw-Hill.

Finkelstein, S., \& Hambrick, D. C. (1989). Chief executive compensation: A study of the intersection of markets and political processes. Strategic Management Journal, 10(2), 121-134.

Goldberg, L. G., \& Idson, T. L. (1995). Executive compensation and agency effects. Financial Review, 30(2), 313-335.

Gordon, J. N. (2004). Executive compensation: If there's a problem, what's the remedy-the case for compensation discussion and analysis. Journal of Corporate Law, 30, (2004-2005), 675-702.

Grabke-Rundell, A., \& Gomez-Mejia, L. R. (2002). Power as a determinant of executive compensation. Human Resource Management Review, 12(1), 3-23.

Grey-Bowen, J.E., \& McFarlane, .D.A. (2010). Gender Compensation Discrimination: An Exploration of Gender Compensation Gap and the Higher Education Connection. Journal of Business Studies Quarterly, 2010, Vol. 2, No. 1, pp. 65-82. Retrieved from http://jbsq.org/wp-content/uploads/2010/12/JBSQ_5F.pdf

Grossman, W., \& Hoskisson, R. E. (1998). CEO pay at the crossroads of Wall Street and Main: Toward the strategic design of executive compensation. The Academy of Management 
Executive, 12(1), 43-57.

Harris, J. D. (2009). What's wrong with executive compensation? Journal of Business Ethics, $85(1), 147-156$.

He, L. (2008). Do founders matter? A study of executive compensation, governance structure and firm performance. Journal of Business Venturing, 23(3), 257-279.

Jones, G.R., \& George, J.M. (2009). Contemporary Management (Sixth edition). Boston, MA: McGraw-Hill Irwin.

Kostiuk, P. F. (1990). Firm size and executive compensation. Journal of human Resources, Vol. 25, No. 1 (Winter, 1990), 90-105.

Kuhnen, C. M., \& Zwiebel, J. (2007). Executive pay, hidden compensation, and managerial entrenchment. Retrieved from http://citeseerx.ist.psu.edu/viewdoc/summary?doi=10.1.1.209.609

Lime, D. (2013). 466 Hours of Worker Overtime Equals One Hour of CEO Pay.

NerdWallet.com, December 6, 2013. Retrieved from

http://www.nerdwallet.com/blog/investing/2013/466-hours-overtime-equals-hour-ceo-pay/

McIntyre, D.A. (2014). Nine College Presidents Made Over \$1 Million, One Made Under $\$ 15,000.24 / 7$ Wall St. Newsletter, May 19, 2014. Retrieved from

http://247wallst.com/economy/2014/05/19/nine-college-presidents-made-over-1-million-onemade-under-15000/

Mehran, H. (1995). Executive compensation structure, ownership, and firm performance. Journal of Financial Economics, 38(2), 163-184.

Murphy, K. J. (1994). Politics, economics, and executive compensation. University of Cincinnati Law Review,63, 713.

Narayanan, M. P., \& Seyhun, H. N. (2005). Effect of Sarbanes-Oxley Act on the influencing of executive compensation. Effect of Sarbanes-Oxley Act on the Influencing of Executive Compensation (November 2005). Retrieved from http://sitemaker.umich.edu/m.p.narayanan/files/060320replag.pdf

Nelson, D.L., \& Quick, J.C. (2007).Understanding Organizational Behavior. Stamford, CT: Cengage Publishing.

NerdWallet.com. (2013). 466 Hours of Worker Overtime Equals One Hour of CEO Pay.

Retrieved from

http://www.nerdwallet.com/blog/investing/2013/466-hours-overtime-equals-hour-ceo-pay/

Nichols, D., \& Subramaniam, C. (2001). Executive compensation: Excessive or equitable? Journal of Business Ethics, 29(4), 339-351.

Peterson, H. (2013). McDonald" and Starbucks' CEOs Make More Than \$9,200 an Hour. Business Insider, December 10, 2013. Retrieved from 


\section{Macrothink}

Journal of Entrepreneurship and Business Innovation ISSN 2332-8851 2015, Vol. 2, No. 1

http://finance.yahoo.com/news/mcdonalds-starbucks-ceos-more-9-110100507.html

Sapp, S. G. (2008). The impact of corporate governance on executive compensation. European Financial Management, 14(4), 710-746.

Sridharan, U. V. (1996). CEO influence and executive compensation. Financial Review, 31(1), 51-66.

Staw, B.M. (1986). Organizational Psychology and the Pursuit of Happy/Productive Worker. California Management Review, Volume XXVIII, Number 4, Summer 1986, 40-53.

Wright, T.A., \& Cropanzano, R. (2000). Psychological well-being and job satisfaction as predictors of job performance. Journal of Occupational Health Psychology, Volume 5(1), Jan 2000, 84-94. doi: 10.1037/1076-8998.5.1.84 